\title{
Action Research on Teaching Assistant Program for Business English Major Courses-Taking Integrated Business English as an Example
}

\author{
Sun Yangzi \\ English Department, School of Foreign Languages \\ Dalian Neusoft University of Information \\ Dalian, China \\ yangzi_1004@hotmail.com
}

\begin{abstract}
As one of the basic core courses for Business English majors, Integrated Business English enjoys several characteristics such as a large number of class hours, intensive class arrangements and heavy construction tasks, which are all big challenges for both lecturers and students. For courses with such demanding characteristics, it is particularly necessary to establish a teaching assistant program. This paper takes the teaching assistant program for the course, Integrated Business English taught in the author's university, as the research object, adopts the method of action research and combines the observation method, questionnaire method, and interview method to study the design and implementation of the teaching assistant program. With the aim to provide suggestions and references for the establishment of teaching assistant programs for other courses, this paper also discusses the effects of the program and reflects on the further improvement measures.
\end{abstract}

Keywords-Teaching assistant program; Integrated Business English; Business English major; Action research

\section{INTRODUCTION}

The teaching assistant program has been implemented in western universities for a long time, with the work mostly undertaken by postgraduates. The working scope of teaching assistants in foreign universities is generally divided into two categories, Professional Development and Graduate Employment [1]. Many Chinese universities have also adopted the teaching assistant program and now it is also graduate students who are assisting teachings. On the one hand, it is contributive to reducing the workload for teachers. On the other hand, it also helps enhance the assistants' own professional knowledge and their capabilities to teach and conduct research. However, in institutes that have not yet established postgraduate programs, the demand for teaching assistant program is also worth noticing and how to establish a teaching assistant program in the absence of graduate students becomes a subject worth studying.
II. The Necessity of Establishing Teaching Assistant Program in INTEGRATED Business English

Faced with the trend of internationalization in the new era, Business English majors are trained to be English-speaking professionals with solid English language competences and programmatic international business management theory, and equipped with strong practical skills. As a basic core course for the lower grades of Business English majors, Integrated Business English takes the training of language competences, inter-cultural communication competence, and business communication competence as its teaching objectives, so that students can use English as a tool for oral and written communication on general business-related topics.

The establishment of teaching assistant program is particularly necessary for Integrated Business English for two reasons: (1) the comprehensiveness of the curriculum development objectives requires the course to be designed with large teaching hours ranging from 96 to 128 hours for each term from the first year to the second. The lecturers are forced to undertake a significant load of teaching tasks and assignment grading tasks. Teaching assistants could partly release their work pressures on assignment grading. (2) The course resources construction also demands lectures to spend a large amount of time on teaching materials designing and collection, which could also be facilitated by assistants who are competent at language teaching.

\section{ACtion RESEARCH ON THE TEACHING Assistant PROGRAM FOR INTEGRATED BUSINESS ENGLISH}

This study used the action research model proposed by the famous German-American psychologist Kurt Lewin to study the teaching assistant program for the course, Integrated Business English, taught in the undergraduate stage. Kurt Lewin introduced the concept of "action research" in his paper Action Research and Minority Problems in 1946, describing "action research" as "a comparative research on the conditions and effects of various forms of social action and research leading to social action" that uses "a spiral of steps, each of which is composed of a circle of planning, action and fact-finding about the result of the action" [2]. The basic characteristic is to involve the researchers (such as the actual workers) in the research, and to apply the results of the study directly to the change of program and behavior, emphasizing 
that the action function of the research is the practical meaning of the improvement action. Action research is a spiral development process, with three stages included in each spiral development circle, namely planning, action, and results. The three stages of this action research will be described in the following parts.

\section{A. Planning}

1) Demand Analysis. While the construction of course resources was shared by all the lecturers in the course team of Integrated Business English, each lecturer had to teach one class (which means 6-8 teaching hours a week), combined with other teaching tasks and work. For them, it was necessary to equip one teaching assistant for each lecturer.

2) Job Responsibilities and Requirements. Teaching assistant responsibilities include monitoring students' learning conditions, assisting the construction of teaching resources, correcting students' homework, sharing learning experience with students and so on. Based on the above responsibilities, teaching assistants are required to be outstanding in English competences (passed TEM-4, grade ranking: 10-15\%) and communication skills, together with a sense of responsibility and optimistic personality.

3) Recruitment. In view of the fact that the university in which the study was conducted has not yet established programs for graduate study in English, the recruited teaching assistants were mainly junior and senior undergraduate students. Students who had the intention to enroll and meet the criteria for the selection were required to undergo a written examination (taking the textbook of Integrated Business English as the source of the test), English interview, job training, and one-month probation period to be identified as eligible for employment.

4) Payment and Rewards. In order to encourage outstanding students to be teaching assistants and to reward them for their excellent performance, the following incentives were offered to teaching assistants: 8-10 yuan/hour payment, score bonus for 1 selected course, work certificate, independent choice of graduation paper instructor and so on.

\section{B. Action}

The team of teaching assistants was under the supervision of a teacher (who was also one of the lecturers teaching the course) working as both a coordinator and a supervisor. The teacher was responsible for the recruitment and daily management of the team, which included working hour reporting, working schedule planning, experience-sharing session organization and workshop organization, etc. The specific work was carried out by the assistants under the supervision of the teacher. However, due to the limitation of professional level, the teaching assistants were not allowed to directly participate in the teaching sessions in class, and were thereby mainly responsible for the auxiliary work in the following aspects:

1) Teaching resources construction. Teaching assistants helped the lecturers complete the curriculum resource construction work, including the construction of curriculum supporting resources (video, audio, ppt of the texts, etc.), the construction of exercise database, the designing and production of MOOC resources, and the designing of self-learning guides.

2) Quiz corrections and test results analysis. Since there was quiz session in each teaching session of the Integrated Business English course, which means there were 90-120 quiz papers (with 3-4 teaching sessions every week and 30 students in each class) to check, the amount of quiz corrections work was enormous. The teaching assistants needed to assist the lecturers to complete the quiz correction work, and found the frequently-made errors by students, to summarize the knowledge points that needed to be readdressed in the feedback session for the lecturers. They could also use their analysis results as references for after-class tutoring in the College English Learning and Tutoring Center, to provide students with personalized homework counseling and answering services.

3) College English Learning and Tutoring Center. The daily management and operation of the center were under the guidance of the supervising teacher. Teaching assistants had to follow a working schedule to provide students with tutoring services for English learning (listening, speaking, reading, writing and translating), assignment counseling, and so on. Learning experience sharing sessions and workshops were also regularly organized here.

4) Work reflections and experience sharing discussions. In order to solve common problems in a timely manner and improve the efficiency and quality of teaching assistants work, all the assistants regularly gathered together to reflect on their work performance and discuss on the problems they had encountered during the work. Lecturers were sometimes invited to participate in the discussion.

\section{Results}

After one year of implementation, a series of questionnaires and interviews were conducted among students, lecturers, and teaching assistants, to assess the effects of the teaching assistant program for Integrated Business English from different angles. 131 students, 6 lecturers, and 6 teaching assistants participated in the evaluation process. The survey results show that the effectiveness of the program was reflected in the following aspects:

First, the "one-way" interaction between lectures and students has been successfully transformed to a more flexible and effective mode.

In the traditional interaction mode between the lecturer and the students (as is shown in Figure 1.), students are mostly the recipients of lecturer's instructing work. The correction of assignments is usually done by the lecturer after class and feedback is provided in class. For the lecturer, it is difficult to give individual feedback to the students in time when the class is large and the preparation task is heavy. The Q\&A session is also basically completed during class. Even for small classes of around 20-30 students, it is impossible for the lecturer to monitor the learning situation of each student. If students want an individual instruction from the lecturer, they would have to book a time in advance and timely feedback could not be easily provided. Due to the lack of feedback mechanism and the lack of guidance and supervision of the students' learning, 
teaching contents are mostly taught to students in a "passive input" manner. For students, most of the communication with lecturers can only be conducted in the classroom, and there are fewer opportunities for personalized counseling and Q\&A session. Extracurricular learning methods, such as group study, are certainly helpful for learning. But for an English language learner, especially for those who are still on the preliminary level (with no comprehensive training as is done on the university level), without professional and personalized guidance, it is still difficult to effectively improve English language skills.

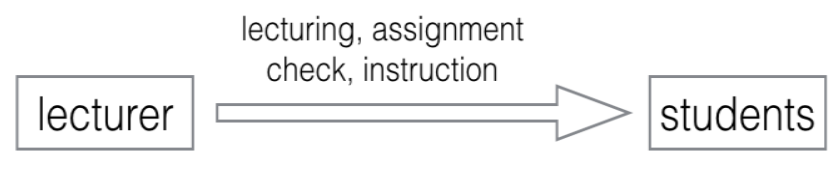

\section{Fig. 1 THE "ONE-WAY” INTERACTION MODE}

The core essence of the teaching assistant program is to establish a bridge between the lecturer and students (as is shown in Figure 2.). First of all, the teaching assistant can learn about the teaching objectives and teaching contents by co-preparing lessons and attending teaching seminars with the lecturers, so as to better complete the work of correcting the assignment and tutoring after class. After completing the homework correction, the assistant would generally summarize the weak points that students have trouble grasping and provide timely feedback to the lecturer in the form of oral or written reports. And the lecturer can conduct targeted instruction according to the feedback from the teaching assistant. In addition, the interviewed teachers also said that with the help of teaching assistants, they could also allocate more energy from the heavy correction work to personalized individual guidance to students.

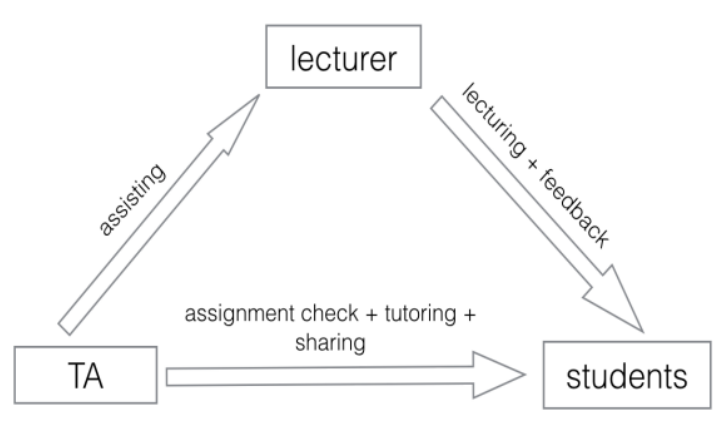

Fig. 2 THE TRANSFORMED INTERACTION MODE

Secondly, guidance from peers stimulates students' interest in learning and improves learning outcomes.

A total of 16 questions were set up for the questionnaire distributed to students, including the following latitudes: (1) the familiarity with the teaching assistant; (2) the interaction with the teaching assistant; (3) the satisfaction with the teaching assistant; (4) the need for assistant teaching in other courses.

Among the respondents, $74.81 \%$ of the students have received individual teaching guidance from the teaching assistants; $60.31 \%$ of the students have participated in the learning experience sharing seminar hosted by the teaching assistants; $74.05 \%$ of the students have sought help in College English Learning and Tutoring Center; $92.37 \%$ of the students were satisfied with the teaching assistants' work; only $17.56 \%$ of the students thought that the teaching assistants exerted " no substantial effect" on their English learning; $72.52 \%$ of the students hoped that the teaching assistant program should continue to the next phase of their study.

According to the survey results, most of the students have benefited from the teaching assistant program. They said that it would be easier for them to obtain reproducible, actionable and practical learning suggestions from the teaching assistants because of the same learning environment. In the process of interacting with the teaching assistants, they felt less pressure than with the instructors, which also made it possible for them to express the difficulties and doubts they have encountered in the learning. The teaching assistant can also understand the voice from the students and hear relatively genuine concerns from them and deliver the message to the lecturers more objectively.

Thirdly, teaching assistants have also benefited substantially from their teaching assistant work. 
According to the results of the questionnaires and interviews, all the teaching assistants believed that they have improved their English learning ability, teaching and research abilities, and interpersonal skills. Since most students seek help about the homework or exams from them, they also need to spend more time getting familiar with the teaching contents, which also impelled them to consolidate the application of English language knowledge. In addition, their corresponding instructors also helped them a lot in improving their teaching and research abilities. Under the leadership and influence of the instructors, the teaching assistants could learn about the production of MOOC and the latest multimedia assisted teaching software. In the process of attending lectures and participating in teaching and research seminars, they have also obtained teaching experience from the teachers. For those who are intended to pursue a teaching profession, it would also be an opportunity for them to accumulate second-hand teaching experience from the teaching practitioners. Meanwhile, teaching assistants had to apply different communication strategies in the process of interpersonal communication with their corresponding instructors and students, which is also helpful for their improvement of communication skills.

\section{SUGGESTIONS FOR IMPROVEMENT}

Based on the results from the first round of practice, it is found that there are also many problems in the implementation of the teaching assistant program, and there is still room for improvement in future work.

First of all, a comprehensive rewards and punishment system and a performance appraisal system should be established. At the initial stage of their teaching assistantship, the teaching assistants were enthusiastic and actively sought solutions when they encountered problems. However, in the later period, especially when they had to deal with heavy classwork for senior courses and seek for internships, they found it difficult to devote themselves in their teaching assistant job, and the enthusiasm of teaching assistants was gradually decreasing. Even with a number of incentives pushing them continuing their job, some of the teaching assistants were "occasionally active and barely able to complete the task". The reason is that there is still a lack of an effective rewards and punishment system and a performance appraisal system. For example, under the premise of protecting the basic rights and interests of students, punishments on the violation of working rules and even dismissal could reduce the likelihood of malfeasance.

Secondly, providing services that stimulate students to change from passively receiving tutoring to actively seeking for help. According to the questionnaire, $49.62 \%$ of the students surveyed "prefer self-study", and $30.53 \%$ of the students surveyed said, "teacher would talk about it in class anyway, so there is no use wasting time with the teaching assistants". Accustomed to the teaching mode of junior high school, freshman students are still depending too much on the lecturers. The awareness of cooperative learning and study group is not strong enough to motivate them to be active. Teaching assistants should be encouraged to reach out to students, create opportunities for interaction, and enhance mutual understanding and trust.

\section{SUMMARY}

Through this action research, the necessity of establishing a teaching assistant program for the basic core courses of the Business English major is proposed, which is not only a supplement to the traditional interaction mode between lecturers and students, but also a facilitation to cooperative learning. Lecturers, students, and teaching assistants themselves can all benefit from the program. Even if there are still improvements to be made, the overall effects are more obvious. However, we must also see that this is only a case study. Whether it can be promoted in other courses and other universities remains to be further studied.

\section{ACKNOWLEDGMENT}

Based on the 2017 School-level Education and Teaching Reform Research Project of Dalian Neusoft University of Information, "Exploration and Practice of OBE Education Model in the Course Construction of Integrated Business English".

\section{REFERENCES}

[1] Shi Shaojie, "The Teaching Mechanism and Guidance of Postgraduate Teaching Assistants in Foreign Universities," (In Chinese) in Contemporary Teacher Education, vol. 8, 2015, pp. 60-64.

[2] JENNIFER S, BOMAN, “Graduate Student Teaching Development: Evaluating the Effectiveness of Training in Relation to Graduate Student Characteristics" in Canadian Journal of Higher Education, 2013, 43 (1), pp. $100-114$.

[3] Chen Shanman, Wang Yuan, "Research on the Reform Action of Flipping Classroom Teaching Based on Network Resources" (in Chinese) in Education Review, vol. 7, 2016, pp. 12-13.

[4] Chen Xiangming, Qualitative Research Methods and Social Science Research (In Chinese). Beijing: Education Science Press, January 2000.

[5] Qi Guanghong, "Action Research on Assisting Teaching Experiment Teaching" in "Team Work" Course-Taking Experimental Teaching Reform in a University as an Example," (In Chinese) in Journal of Zhejiang Youth College, vol. 3, 2010, pp. 41-45.

[6] Wang Zhiyuan, "Action Research of Integrated English Classroom Interaction Model Based on "Information Difference," (In Chinese) In Foreign Languages Research, vol. 1, 2015, pp. 53-56. 